\title{
Foreword
}

\section{Cowbirds and Bull-hockey}

As the loss of biodiversity escalates, a determined effort is being made to convince people that there is nothing to worry about-that there is no extinction crisis (Simon and Wildavsky 1993). This effort is part of a broader campaign to quell environmental concerns, an antiscience outflowing of rhetoric in support of the wise-use movement that has been christened the "brownlash" (Ehrlich and Ehrlich 1996). The depth of ignorance represented in the brownlash is difficult to overestimate. Consider the following statement: "North and west of New York City and London and Chicago, south of Paris and Bonn, east of San Francisco and Moscow, in all directions around Atlanta and Denver and Warsaw and Madrid, and in many similar locations worldwide, extensive tracts of habitat that have known only occasional human intervention abut centers of mechanistic excess" (Easterbrook 1995, p. 9).

Think about going east from San Francisco, through grossly polluted San Francisco Bay with some $90 \%$ of its wetlands destroyed, through fully developed and smog-soused East Bay cities and suburbs to the plowed-under Central Valley, virtually devoid of even remnant natural habitat, with most of its native flora and fauna gone, and now populated by cowbirds whose invasion was aided by anthropogenic habitat changes (Rothstein 1994). In fact, one could continue eastward around the world without finding any "extensive tracts of habitat that have known only occasional human intervention," unless one wished to stretch that definition to include some ocean depths.

However, just getting to the cowbirds in California's Central Valley allows me to make the points I want to emphasize here. First, most people are ignorant of the degree to which Homo sapiens has modified the biosphere. Second, although biodiversity loss is usually characterized in terms of the rate of species extinction, population extinction is also very important. Third, invasions and subtle community alteration are crucial factors in the extinction epidemic. And finallyas Ecology and Management of Cowbirds and Their Hosts amply demonstrates-the cowbird makes a fascinating case study illustrating these points.

In the past 150 years, humanity has become a global force. Measured by energy use-the best general surrogate for the power to do environmental damage-the human enterprise has expanded roughly 20-fold since 1850 (Holdren 1991). The current state of global overpopulation is evident because humanity is unable to support itself solely on income from its natural capital, but only by also depleting that capital. This is most readily seen in loss of deep, rich agricultural soils, "fossil" groundwater, and, of course, biodiversity (Ehrlich and Ehrlich 1990).

In the last case, emphasis has been placed much too heavily on the extinction of entire species, whereas from the viewpoint of the all-important delivery of ecosystem services (Daily 1997), population extinctions are equally or more important (Ehrlich and Daily 1993). After all, if all remaining nonhuman species could be preserved as minimum viable populations in zoos, aquaria, botanical gardens, and buckets of soil, there would be no loss of species diversity. Nonetheless we would all quickly die from starvation and other consequences of the termination of ecosystem services. Thus, one question of great interest in relationship to cowbirds is how they have (or have not) contributed to the population extinctions that have afflicted a substantial fraction of neotropical migrants.

Continuing population growth and increasing per capita consumption are bound to increase those losses, almost certainly reducing Earth's carrying capacity for Homo sapiens, since there is little sign that making technologies more environmentally friendly can or will compensate for expanding human numbers and affluence. Thus whatever the role of cowbirds in the critically important extinction of populations (as well as, of course, species) of their hosts, it will be played out on a stage modified by increasing anthropogenic disruption.

The role of people in causing extinctions is often seen pri- 
marily as overhunting (as typified by the extermination of the Passenger Pigeon, Dodo, Eskimo Curlew, and numerous populations of bison, wolves, snow leopards, elephants, rhino, whales, and oceanic fishes) and outright habitat destruction (as in the cases of the Ivory-billed Woodpecker, Bachman's Warbler, and many populations of Northern Spotted Owls, lemurs, black-footed ferrets, prairie plants, and Edith's checkerspot butterfly) (e.g., Ehrlich and Ehrlich 1981, Ehrlich et al. 1992). There is much less public recognition of the role of invasions in causing extinctions (Heywood 1995). Avian extinctions, of course, are most clearly seen in the extirpation of entire species from numerous islands by invading Homo sapiens and the animals they transported with them (e.g., King 1984, Steadman 1989). Very often, of course, hunting, habitat destruction, invasions, and the vulnerabilities associated with small population size can all conspire to do in a species, as in the case of the Tasmanian tiger or thylacine (Lunney and Recher 1986).

Sometimes the alterations associated with invasions are so long-standing and widespread that it is very difficult to evaluate their overall impact. For example, it is highly likely that the movement of people into the western hemisphere was a major cause of the Pleistocene megafaunal extinctions (Martin 1984). These, in turn, transformed the landscape of the Americas, creating shifts in community structure and causing other extinctions of populations and species (Guthrie 1984, Owen-Smith 1989), most of which were unrecorded. More recent but probably equally transforming has been the overgrazing and consequent desertification of much of the western United States (e.g., Ferguson and Ferguson 1983, Jacobs 1991), which also certainly led to many population extinctions.

The inevitability of such unsung anthropogenic extinctions has been made even clearer by recent advances in our understanding of the subtlety of habitat requirements. Who, for example, might have imagined that the persistence of Tree and Violet-Green Swallow populations in some subalpine areas would depend on the co-occurence of sapsuckers, aspens, willows, and a fungus (Daily et al. 1993)?

There would seem to be a prima facie case that cowbird populations have a negative impact on the dynamics of their host populations. In several cases, such as those of the Black-capped Vireo and Kirtland's Warbler, remnant populations of endangered species have been threatened by very high rates of cowbird parasitism. In some cases, cowbird removal programs have been part of the operations designed to rescue these species from imperilment. The results, as you will see in the chapters that follow, are variable and sometimes difficult to interpret.

This book underlines several important issues in conservation biology. First of all, in many cases biologists already know more than enough to suggest sensible starting directions for trying to protect biodiversity-both globally and in specific cases. Undertaking cowbird control programs in various cases has been such a sensible direction at the local level. But conservation efforts almost always involve allocation questions, and cowbird control may not be the best place to target scarce available funds. That's where the need for further scientific investigation arises. We need to discover the least expensive steps that will accomplish conservation goals. But that need can, in turn, present difficult trade-offs between the use of funds for continuing conservation efforts such as control programs or purchasing or restoring more habitat, and for determining the relative values of cowbird control and habitat protection and restoration. Resolving such dilemmas is daunting, but conservation biologists should at a minimum always be explicitly aware of them.

Fortunately, the evolutionary and ecological questions surrounding an abundant brood parasite that has recently expanded its range widely are so fascinating, as Ecology and Management of Cowbirds and Their Hosts iliustrates, that research on cowbird biology would doubtless continue even if cowbirds had negligible impact on threatened or endangered species. The information in this volume would be of great value to biologists even if there were no need to put "management" in the title. Finally, as conservation biologists struggling to protect elements of biodiversity at local and regional levels, we should never forget the global picture. Unless expansion of the scale of the human enterprise can be halted soon, virtually all of the populations and species that may or may not now be threatened with extinction by cowbirds will disappear. They will go extinct from the effects of habitat destruction, climatic change, toxification, or other anthropogenic causes interacting with each other and perhaps with cowbird parasitism. After that, continued increase in human numbers and per capita affluence could make it a question of whether industrial civilization or the cowbirds themselves will disappear first. The kind of bullhockey produced by the brownlash makes having to face that question ever more likely.

\section{References Cited}

Daily, G., P. Ehrlich, and N. Haddad. 1993. Double keystone bird in a keystone species complex. Proc. Natl. Acad. Sci. USA 90: 592-594.

Daily, G. C. (ed). 1997. The value of ecosystem services. Island Press, Washington, DC.

Easterbrook, G. 1995. A moment on the earth: The coming age of environmental optimism. Viking, New York.

Ehrlich, P. R., and G. C. Daily. 1993. Population extinction and saving biodiversity. Ambio 22:64-68.

Ehrlich, P. R., D. S. Dobkin, and D. Wheye. 1992. Birds in jeopardy. Stanford University Press, Stanford, CA.

Ehrlich, P. R., and A. H. Ehrlich. 1981. Extinction: The causes and consequences of the disappearance of species. Random House, New York. 
1990. The population explosion. Simon and Schuster, New York.

1996. Betrayal of science and reason: How anti-environmental rhetoric threatens our future. Island Press, Washington, DC.

Ferguson, D., and N. Ferguson. 1983. Sacred cows at the public trough. Maverick Books, Bend, OR.

Guthrie, R. D. 1984. Mosaics, allelochemics, and nutrients: An ecological theory of late Pleistocene megafaunal extinctions. Pp. 259298 in Quaternary extinctions: A prehistoric revolution. (P. S. Martin and R. G. Klein, eds). University of Arizona Press, Tucson.

Heywood, V. H. (ed). 1995. Global biodiversity assessment. Cambridge University Press, Cambridge.

Holdren, J. 1991. Population and the energy problem. Population and Environment 12:231-255.

Jacobs, L. 1991. Waste of the West: Public lands ranching. Lynn Jacobs, Tucson, AZ.

King, C. 1984. Immigrant killers: Introduced predators and the conservation of birds in New Zealand. Oxford University Press, Auckland, New Zealand.
Lunney, D., and H. F. Recher. 1986. The living landscape: An ecological view of national parks and nature conservation. Pp. 294-328 in A natural legacy: Ecology in Australia, 2nd ed. (H. F. Recher, D. Lunney, and I. Dunn, eds). Pergamon Press, Sydney.

Martin, P. S. 1984. Prehistoric overkill: The global model. Pp. 354403 in Quaternary extinctions: A prehistoric revolution (P. S. Martin and R. G. Klein, eds). University of Arizona Press, Tucson.

Owen-Smith, N. 1989. Megafaunal extinctions: The conservation message from 11,000 years B.P. Conserv. Biol. 3:404-412.

Rothstein, S. I. 1994. The cowbird's invasion of the far West: History, causes, and consequences experienced by host species. Studies in Avian Biol. 15:301-315.

Simon, J., and A. Wildavsky. 1993. Facts, not species, are endangered. New York Times.

Steadman, D. W. 1989. Extinction of birds in eastern Polynesia: A review of the record and comparisons with other Pacific Island groups. J. Archaeol. Sci. 16:177-205. 
THIS PAGE INTENTIONALLY LEFT BLANK 
Ecology and Management of Cowbirds and Their Hosts 
THIS PAGE INTENTIONALLY LEFT BLANK 